\title{
Application of terrestrial laser scanning in forest inventory - an overview of selected issues
}

\author{
Grzegorz Krok* (iD, Bartlomiej Kraszewski ${ }^{\text {DD }}$, Krzysztof Stereńczak ${ }^{(D)}$ \\ Forest Research Institute, Department of Geomatics, Braci Leśnej 3 St.,Sękocin Stary, 05-090 Raszyn, Poland \\ *Tel. +48 22 7150366, e-mail: g.krok@ibles.waw.pl
}

\begin{abstract}
Precise determination of forest resources is one of the most important tasks in conducting sustainable forest management. Accurate information about the forest's resources allows for a better planning of current and future management as well as conservation activities. Such precise information is needed by both, individual forest managers and for developing the national forest policy. In recent years, interest in the use of remote sensing in forest inventory has significantly increased. Remote sensing allows for non-invasive measurements and the automation of data processing. The most accurate source of remote sensing data at the level of the sample plot is terrestrial laser scanning (TLS). Its use in forest inventory has been studied for about two decades.

This paper aims to introduce studies on state of the art TLS technology as well as provide an overview of research conducted in stands within the temperate climate zone. This article furthermore discusses issues such as TLS data acquisition, data processing and presents results for the estimation of tree biometric features.
\end{abstract}

Keywords: LiDAR, point cloud, forestry, remote sensing

\section{Introduction}

The precise determination of forest resources is one of the most important tasks of sustainable forest management. Accurate information on resources enables planning of current and future economic and conservation activities. This knowledge is also needed for the implementation of sustainable forest management policies. Depending on the purpose, availability of financial resources and required accuracy, many methods of forest inventory are distinguished. Because of the high cost and time involved in field work, foresters often use statistical and mathematical methods based on measurements on circular sample plots. Field crews typically measure characteristics such as diameter at breast height (DBH) and tree height, and determine the species and location of each tree relative to the centre of the sample plot. The time-consuming nature of field work with conventional tools (e.g. tree callipers, compass, altimeter) is driving the search for new, alterna- tive solutions that reduce the cost and labour intensity of inventory and increase its objectivity.

In recent years, a number of scientific papers have been published on the use of remote sensing technologies for forest inventories, in particular Light Detection and Ranging (LiDAR) technology. The product of this technology is a three-dimensional image of reality, consisting of millions of points that form a 'point cloud'. This allows precise measurement of the dimensions and structure of scanned objects (Będkowski 2004; Wężyk 2006). Laser scanners are integrated with different types of platforms, e.g. aerial platform - airborne laser scanning (ALS) or stationary survey tripod - terrestrial laser scanning (TLS). In forest management, due to the vastness of forest areas, data collection by ALS technology is most often considered, as it provides data for entire forest areas in a short period of time (Wężyk 2006; Stereńczak 2010; Będkowski et al. 2011). Many papers have been written on 'enhanced forest inventories' that use ALS data together with field measure-

Received: 25.10.2020 r., accepted after revision: 16.11.2020 r. 
ments to estimate stand characteristics of individual forest compartments with high accuracy (White et al. 2016). In some countries, ALS forest inventory methods are used in forestry practice, e.g. Norway, Finland, Denmark and Sweden (Kangas et al. 2018). The most commonly used forest inventory method using ALS data is the 'area-based approach' (ABA), which uses relationships between point cloud characteristics and ground measurements using statistical methods (Næsset 2002; White et al. 2013; Hawryło 2017). This method allows the development of a predictive model for each surveyed stand characteristic determined from field measurements. Once the mathematical models have been developed, the final step is to apply them to the entire scanned area.

ALS makes it possible to obtain data for vast areas quickly and with relatively little effort. Moreover, the use of ALS together with the field data requires a smaller number of sample plots compared to the traditional statistical and mathematical method, while maintaining the assumed precision of the estimates (Stereńczak et al. 2018). However, it should be emphasised that this method requires some field measurements to calibrate the statistical model, as woody parts of vegetation, including stems, cannot be directly observed using ALS technology (White et al. 2016).

A complementary data source for airborne measurements is TLS data. TLS data represent the image of a stand as seen from the ground beneath the tree canopy. The result of using TLS is a very dense point cloud with measurement accuracy in millimetres (Zawiła-Niedźwiecki et al. 2008, Wężyk 2010). Therefore, this technology is considered the most accurate source of remote sensing data for sample plots (Liang et al. 2018a). An additional advantage of using TLS is the automated and very fast way of obtaining data.

The use of TLS in forestry has a relatively short history. The first terrestrial laser scanner was introduced in 1998 (Liang et al. 2016). Pioneering scientific work on the use of TLS in forestry took place at the turn of the $20^{\text {th }}$ and $21^{\text {st }}$ centuries (Tanaka et al. 1998; Aschoff, Spiecker 2004; Henning, Radtke 2006). The main impetus for the use of TLS in forestry was initially to improve field work on sample plots by replacing some of the manual measurements. Early work addressed automatic or semi-automatic solutions based on TLS data aimed at measuring basic biometric characteristics of trees, such as DBH, height and location (Maas et al. 2008; Brolly, Kiraly 2009). With the increasing computational power of computers and the development of data processing algorithms, new opportunities arose for the use of TLS data. They have become a valuable source of information, allowing for the automatic measurement of biometric traits that previously could not be measured directly using traditional forest inventory methods. Many papers have been published on methods for automatically determining tree volume and biomass based on TLS data, in which authors report accuracy comparable to the best national allometric equations (Astrup et al. 2014; Liang et al. 2014). The potential of this technology has also been recognised in forest ecology research. The suitability of TLS has been demonstrated for determining LAI (leaf area index) and studying the dynamics of changes in stand gaps and crown structure (Liang et al. 2016).

Polish scientific centres have also been studying the use of TLS in forestry for several years. These studies mainly concern forest inventory issues (Chirrek et al. 2007; Wężyk et al. 2007; Chmielewski et al. 2010; Wężyk, Sroga 2010; Zasada et al. 2013; Ratajczak, Wężyk 2015), but also such as determination of DBH distribution (Zasada, Stereńczak 2013), urban greenery inventory (Tompalski 2009) and monitoring the condition of natural monument trees (Wężyk et al. 2015).

This paper is a synthetic review of research on the use of TLS technology conducted in temperate tree stands for about 20 years. In this paper, the authors focused particularly on the practical aspects of using TLS technology for forest inventory and on summarising the achieved measurement accuracy of the main biometric characteristics of trees. In the Discussion section, the authors evaluate the possibility of introducing this technology into forestry practice.

\section{How TLS works and types of scanners}

TLS scanners work by measuring the distance and the horizontal and vertical angle between the device and the object under investigation using light beams (lasers) emitted by the device.

TLS measurements are made from a stationary position in designated locations, with the scanner placed on a survey tripod. During operation, the scanner registers the image of the surroundings, rotating around its own axis. The measurements performed by the device allow to determine the $\mathrm{X}, \mathrm{Y}, \mathrm{Z}$ coordinates of millions of measurement points, which form the so-called point cloud. In addition to registering the point coordinates, terrestrial laser scanners also record the intensity of the reflected signal, i.e. the value of the energy of the returning light beam (reflected from the object). Digital cameras are also integrated in TLS scanners, which makes it possible to assign real colours (RGB) from the digital images to each point 
of the cloud (Wężyk 2010). Currently, several models of terrestrial laser scanners are available on the market, which can be divided into two main groups: time-of-flight (ToF) and phase-shift scanners. The main feature that distinguishes these two types of scanners is the distance measurement technology.

Phase-shift scanners are believed to measure more accurately than ToF scanners; however, the data obtained using them is subject to interference, i.e., the presence of noise in the obtained data. It is also worth noting that phase-shi$\mathrm{ft}$ scanners usually have a smaller range of data measurement compared to ToF scanners (Wężyk 2010). A major advantage of ToF scanners is the ability to register multiple reflections of the laser beam. This is especially important when scanning objects near vegetation (Liang et al. 2016). For example, when a laser beam falls on the outer edge of a trunk or thin branch, part of the beam bounces off it and the rest of the beam penetrates further and registers the subsequent objects encountered. Currently, there are ToF scanners on the market that can register up to 15 reflections of the laser beam (Riegl 2020).

To learn more about the types of scanners and the principles of their operation, the authors refer to the publications by Wężyk (2006, 2010), Dassot et al. (2011) or Liang et al. (2016).

\section{Acquiring TLS data}

The following subsections describe the general specifications of TLS data acquisition in the forest environment for three levels: sample plot, individual tree and whole stand.

\subsection{Sample plots}

Scanning sample plots using TLS technology is typically performed with a single-scan (SS) or multi-scan (MS) mode of data acquisition. In SS mode, the scanner is located in the centre of the sample plot. The data acquired in this mode represents an image of the stand from one perspective, i.e., as seen from the centre of the sample plot. In the MS mode, data is collected from multiple positions - usually from the centre and outside of the plot or by scanning only from outside positions. When deciding to collect data in this mode, artificial reference markers (spheres or targets) usually need to be set up during fieldwork to allow for later alignment of the data. This method of data collection ensures much greater data completeness compared to the SS mode. After alignment, data acquired in the MS mode represent a comprehensive, fully three-dimensional image of the sample plot (Wężyk 2010; Liang et al. 2016).

When comparing the two methods of data collection, it should be noted that the SS mode is much faster. Currently, it takes about $20 \mathrm{~min}$ to perform such a measurement on a sample plot. The measurement time depends mainly on the class of laser scanner used and the settings used during operation. The data acquisition process itself takes between 2 and $10 \mathrm{~min}$, and to this time must be added the time for setting up, starting, and configuring the scanner, which is about 5-10 min (Liang et al. 2016). The main disadvantage of data acquisition in SS mode is the high probability of the so-called 'occlusion effect' (Zasada et al. 2013). This effect causes some trees to be missed in the point cloud of the sample plot being mapped (Fig. 1) because trees in the same azimuth relative to the centre of the plot occlude each other. This effect increases with increasing distance from the scanner, i.e. the larger the radius of the sample plot, the more likely this effect occurs. The authors state in their papers that the percentage of undetected trees in a sample plot using the SS mode can range from 0 to $46 \%$, with stand structure and sample plot size reported as the factors that have the greatest influence on this phenomenon (Astrup et al. 2014). In comparison, four or five scan positions are typically used to map the sample plot in MS mode. The scan positions are arranged in such a way that they map all trees from all sides as much as possible. Data obtained in this mode are considered the most accurate and also provide a complete three-dimensional image of the stand (the entire shape and stem area of each tree is mapped). The disadvantages of this mode include: higher labour intensity for field work, longer time for processing and aligning the point clouds, and a much larger amount of data collected. Currently, it is estimated that it takes about $1 \mathrm{~h}$ to measure a sample plot in MS mode. In MS mode data acquisition, an additional step of aligning the scans takes place during the initial processing. This is done using special software in an automatic or semi-automatic way (Liang et al. 2016).

\subsection{Indivdual trees}

TLS data can also be obtained on individual trees (Fig. 2). Such data can be useful in improving or developing allometric equations for characteristics such as whole-tree volume or biomass. The major advantage of using TLS technology for these purposes is the non-invasiveness, speed, and precision with which information on the morphological stem curve is obtained. Scanning of individual trees is usually performed in MS mode to obtain data 

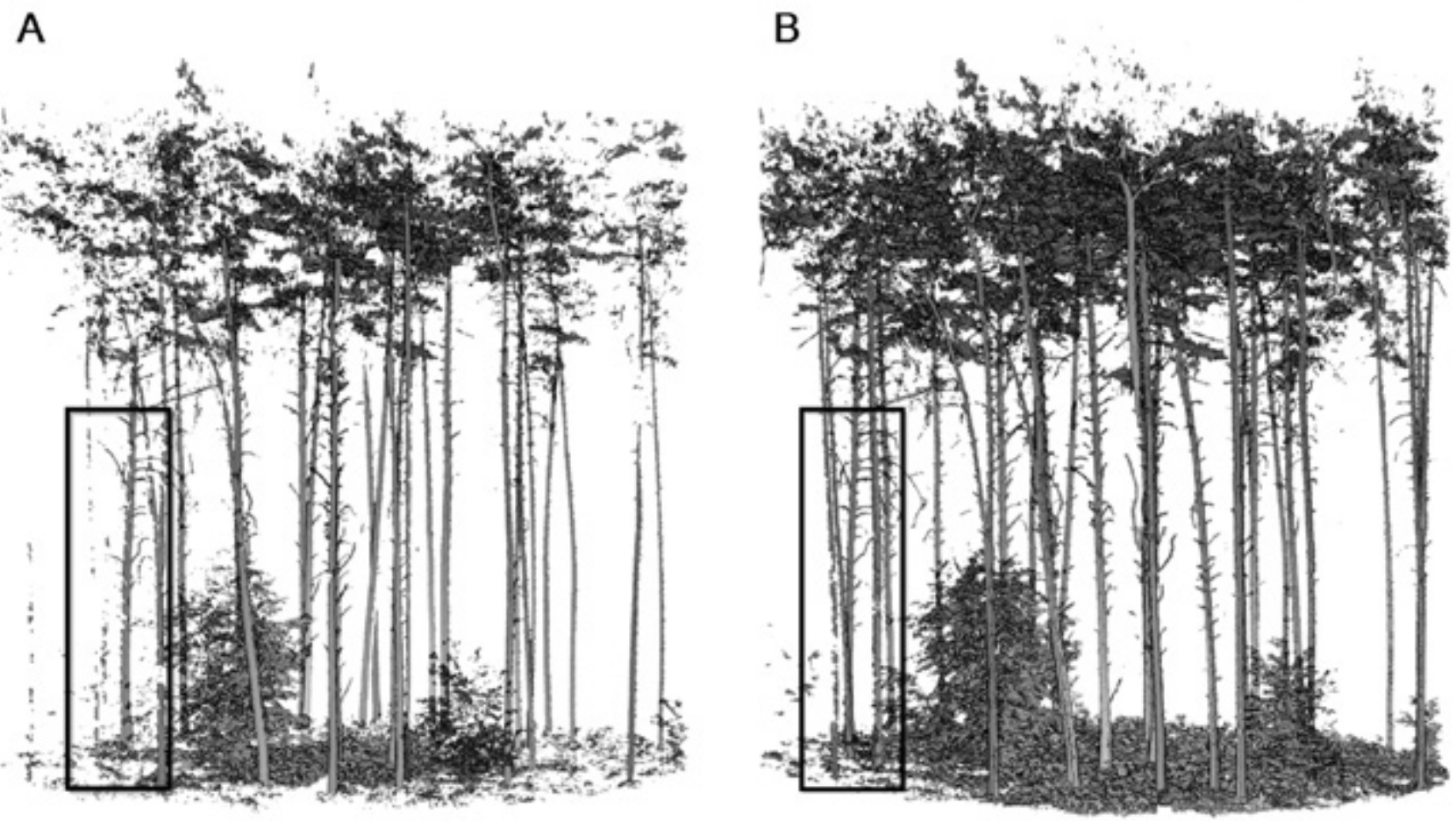

Figure 1. TLS point cloud representing sample plot in a Scots pine stand Pinus sylvestris L.: A - single-scan mode (SS), B - multi-scan mode (MS). The black rectangle shows unregistered trees in SS mode (occlusion effect). Color scheme: Intensity values, visualization was made in CloudCompare software (Girardeau-Montaut 2020).

with the highest level of detail. During fieldwork, scanner locations are positioned around the tree. Raumonen et al. (2013) suggest taking measurements from no less than three positions. However, it should be noted that the number of scanner positions should be chosen depending on the size of the object to be scanned and the planned level of detail of the data (Wilkes et al. 2017). For example, Wężyk et al. (2015) used 4 to 23 scanner positions during a field survey of the natural monument the Bartek Oak. In 2020, employees of the Forest Research Institute (IBL) scanned another natural monument - the Mieszko Oak - from 10 positions, which was sufficient to accurately register the appearance of the entire tree.

\subsection{Whole stands}

The MS mode is also used to scan entire stands (Fig. 3). However, the procedure for scanning large areas is usually more complicated, as the reference markers usually need to be repositioned when the locations of the scanning positions change. For more information on this, the authors refer readers to a paper by Wilkes et al. (2017) describing

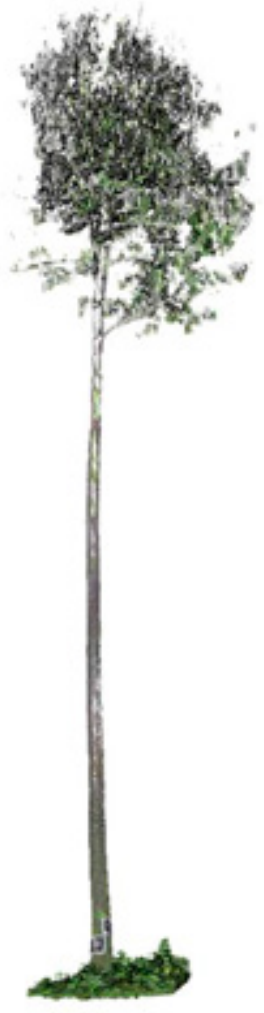

Figure 2. TLS point cloud representing a single tree: Black alder Alnus glutinosa Gaertn. Color schema: natural colors (RGB), visualization was made in CloudCompare software (Girardeau-Montaut 2020). 

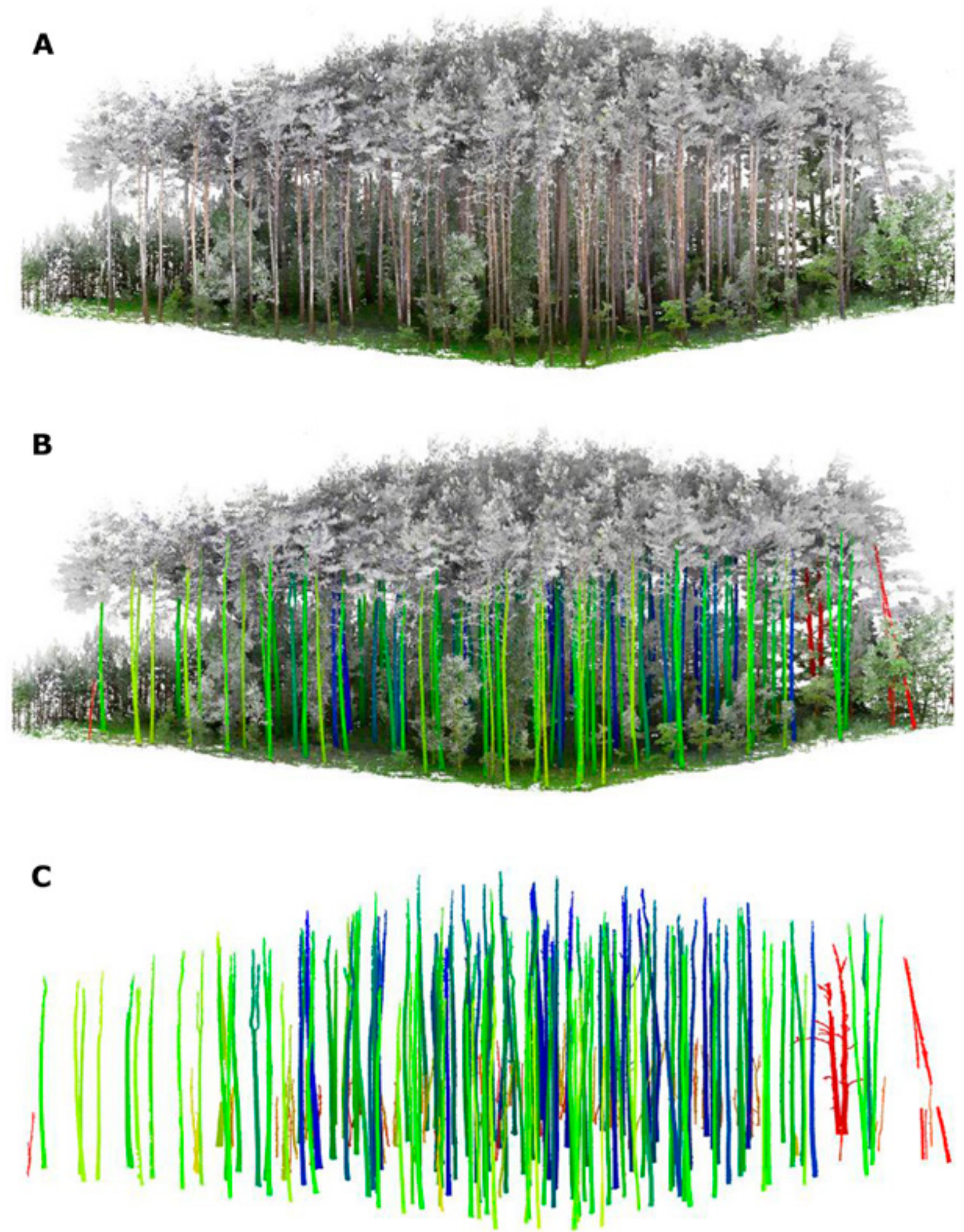

Figure 3. TLS point cloud representing Scots pine stand Pinus sylvestris. A - color scheme: RGB values, B - color scheme: RGB values and different colors for automatically detected tree stems, $\mathrm{C}$ - automatically detected tree stems, visualization was made in CloudCompare software (Girardeau-Montaut 2020). 
their experience from 27 field surveys in which they collected TLS data for large forest areas. They recommend scanning tree stands with a pre-planned $10 \times 10 \mathrm{~m}$ grid where each node of the grid being the location of the scanner, and also recommend setting up about 120 scanning stations for stands of one hectare. Their experience indicates that conducting a TLS scan of a stand with such an area takes between 3 and 8 days for a crew of three in the field. It should be noted, however, that most of this work has been done in tropical rainforests, which are among the most complex stands in terms of vertical structure. In addition, the intensity of the work depends on many factors related to both the stand structure and the type of scanner used. The experience of IBL staff participating in a field study of TLS data collection for two 1 ha forest plots shows that under the conditions of Polish stands, a group of three people may need 2 to 4 days for such measurements of one plot, assuming more than 100 scanning stations for one plot and the use of Riegl VZ-400 or Riegl VZ-400i ToF scanners, which together with the software allow alignment of scans without the need to use reference markers during fieldwork.

\section{Planning a TLS survey}

When planning a measurement acquisition with TLS, the external environmental factors should be considered in addition to the technical aspects, such as the determination of the scan parameters and the selection of the appropriate data acquisition mode.

\subsection{Weather conditions}

When planning a TLS field survey, prevailing weather conditions must be considered (Dassot et al. 2011; Vaaja et al. 2016). Optimal conditions for TLS are windless days with no precipitation, moderate temperatures and low humidity. Wind is a factor that can significantly affect the quality of the data collected, especially within tree canopies. Swaying tree tops during the scan are captured in many places, resulting in image distortion in the upper parts of the stand. According to the study by Seidel et al. (2012), optimal scanning conditions occur when the average wind speed does not exceed $5 \mathrm{~m} / \mathrm{s}$. Vaaja et al. (2016) show that a wind speed of $9 \mathrm{~m} / \mathrm{s}$ only does not significantly affect the stem parameters of the lower part of the tree (the part of the stem below one third of the total tree height).

TLS can be conducted in light rain or fog; however, this is not recommended due to poor data quality and the potential for distortions, i.e. false reflections in the obtained data. Scanning is also not recommended when snow cover is present. Possible layers of snow deposited on the stem (absorbing the laser beams emitted by the scanner) may lead to errors in determining the diameter or volume of the stem (Dassot et al. 2011).

\subsection{Vegetation period}

An important aspect of planning a TLS survey is also the choice of an appropriate scanning date. For surveys that aim to obtain the most accurate data possible on the morphology of the woody parts of trees and to estimate their volume or biomass, the best times to scan are early spring or late autumn. During these periods, deciduous species lack foliage, so the effect of mutual obscuration is much smaller. Data collection during the leaf-off period provides a much better representation of the branches in the crowns of deciduous species and eliminates the potential effect of the lower parts of the stems being occluded by a layer of shrubs from the understory. This aspect is also important when scanning in MS mode with artificial reference markers. In the leaf-off period, the risk of the markers being occluded by leaves from lower forest layers is reduced.

\section{TLS data processing methods}

TLS data processing for dendrometric tree analysis can be divided into two main processes: tree detection in the point cloud and the development of three-dimensional models of individual trees.

\subsection{Detection of trees}

In recent years, a number of studies on automatic algorithms for detecting trees in a point cloud have been developed. In this context, tree detection can be understood either as an indication of the location of trees and their thickness (e.g. DBH) or as an attempt to reconstruct the overall shape and architecture of trees. The first algorithms were based on searching geometric patterns from the generated two-dimensional images representing the horizontal cross-section through a tree stand. The first stage of these methods consists of placing a thin horizontal slice of a three-dimensional point cloud on the horizontal plane. In the next stage, trees are detected by clustering groups of points (Wężyk et al. 2007) and searching for geometric patterns, e.g. circles (Chmielewski et al. 2010, Lindberg et al. 2012). These methods assume that the shape of a point cloud representing tree trunks 
from a horizontal slice is similar to a circle or semicircle. The advantages of these methods include their relative simplicity and high computational speed. However, these algorithms encounter some difficulties in complex stands with high tree density or undergrowth, as the mapped points of the non-woody parts of the stem may be misclassified as a stem (Zhang et al. 2019). To remedy this, some researchers have focused on accurately identifying trunks or woody tree parts directly in the point cloud. In their work on distinguishing the woody or leafy parts of stems in point clouds, authors use different approaches. Côté et al. (2009) assumed that the woody parts of trees have a higher reflectance intensity than leaves and tried to exploit this fact in the classification. However, it should be noted that the reflection intensity of the laser beam depends not only on the spectral characteristics of the scanned objects, but also on the angle of the laser beam, the distance to the scanned object or its roughness. Normalising the value of reflection intensity is again a complicated and time-consuming process (Zhang et al. 2019). The use of dual wavelength laser scanners has also been tested $(\mathrm{Li}$ et al. 2013; Danson et al. 2014). The authors of these papers assumed that due to the distinct differences in the wavelength properties of leaves and woody parts of trees, they could be distinguished in the two wavelength bands. The accuracy of the classification was not discussed in detail in these papers. However, work on the development of such scanners is still in the testing phase and the availability of such devices is currently limited.

Another approach is to use the local geometric features of point clouds. In these methods, the point cloud is divided into small subsets in a first step. Iteratively, for each point, groups of points closest to it are selected, defined by the radius of the sphere or by the number of nearest neighbours around the central point. For selected subsets, geometric features are computed using the principal component analysis (PCA) algorithm (Burt et al. 2018, Zhou et al. 2019). For trunk detection, geometric features of point clouds such as linearity, flatness, and verticality were used. It was assumed that tree trunks in a point cloud are generally vertical objects, are linear, and form relatively flat surfaces at a small scale (Liang et al. 2012; Oloffson, Holmgren 2016). The geometric features are computed for each point in the cloud based on the set of neighbouring points determined by the radius of the distance parameter or the number $\mathrm{n}$ of nearest neighbours. The size of the selected subset affects the discrimination of the objects. For this reason, in some studies, multi-scale geometric features were used to classify the point cloud into woody and soft parts, i.e., leaves. Classification al- gorithms were applied in the studies, using machine learning methods among others (Vicari et al. 2019; Zhou et al. 2019). A major advantage of these methods, in contrast to the previous ones, is the use of geometric information from the point cloud, which should be relatively similar regardless of the specifics of the scanner used. However, it should be noted that these methods require more computational power.

\subsection{Three-dimensional tree modelling}

In the analysis of both individual trees and groups of trees in sample plots or whole stands, the basic unit being analysed is the quantitative structure model (QSM) of a single tree. Such a model is assumed to represent the morphology of the tree as accurately as possible and to be fully measurable (Raumonen et al. 2013; Hackenberg et al. 2015). These properties allow accurate determination of the thickness and volume of the above ground tree components.

Liang et al. (2016) distinguish five levels of detail (LoD) of digital tree models that allow different characterizations of the modelled trees (Table 1).

Depending on the level of details, tree models are used for different tasks. For the purpose of forest inventory, the use of models with LoD from 1 to 3 are mainly considered (Fig. 4).

The use of conventional tools in a traditional forest inventory allows the collection of information at the LoD1 level, where each tree or a selected group of trees is described by two basic characteristics height and DBH. LoD2-level models are much more detailed, as the thickness of the main stem can be measured at each height for which TLS data have been collected. Such models allow stem volume to be measured directly and accurately. LoD3 models also take into account branches, allowing the total biomass and architectural features of trees to be determined. Building such models based on TLS data requires scanning from many positions, which significantly increases the cost of data acquisition. LoD3 and LoD4 models are used in individual tree modelling, while LoD5 models are used in computer graphics, but current TLS technology does not allow obtaining detailed data, such as characterising all tree leaves (Liang et al. 2016).

Many approaches can be found in the literature to generate three-dimensional tree models from a point cloud. The best results are obtained with two approaches. The first is based on the direct reconstruction of the outer surface of objects (meshing), resulting in a three-dimensional, uniform, continuous surface that represents the 
Table 1. Parameters characterizing tree models for given levels of detail, according to Liang et al. (2016)

\begin{tabular}{|c|c|c|}
\hline LoD1 & $\begin{array}{c}\text { tree height } \\
\text { diameter at breast height }\end{array}$ & - \\
\hline LoD2 & $\begin{array}{c}\text { tree position } \\
\text { 3D model of the main stem }\end{array}$ & LoD1 \\
\hline LoD4 & $\begin{array}{l}3^{\text {rd }} \text { level branches } \\
\text { (connected with the } 2^{\text {nd }} \text { level branches) }\end{array}$ & LoD1 + LoD2 + LoD3 \\
\hline
\end{tabular}

A

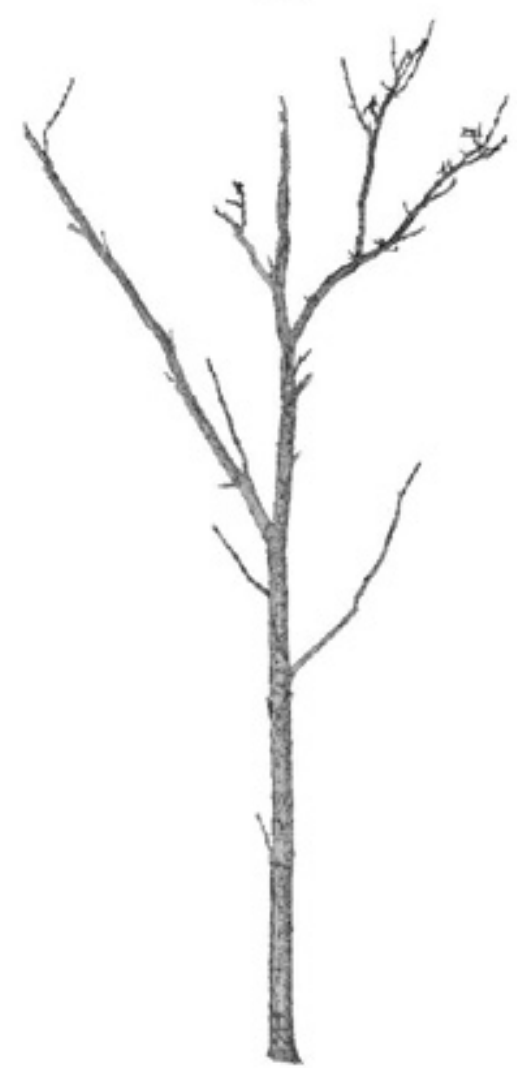

B

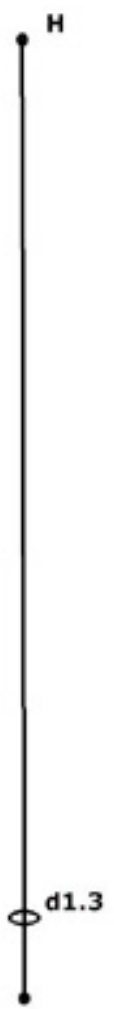

C

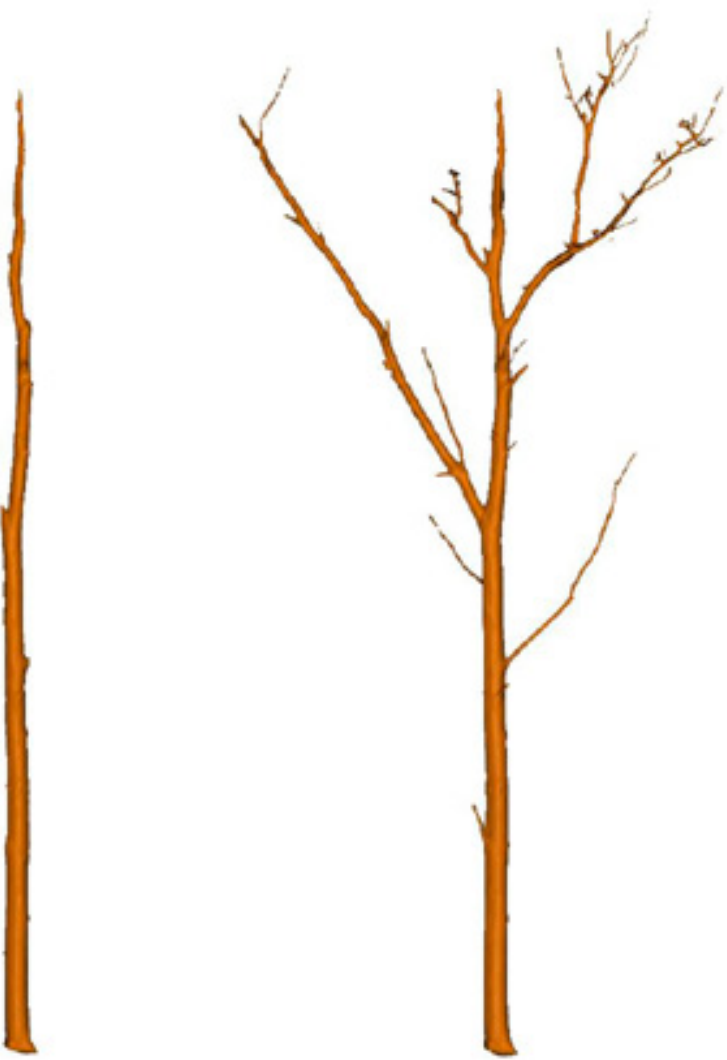

Figure 4. Presentation of details of tree models: A - TLS point cloud, B - LoD1 tree model, C - LoD2 tree model, D - LoD3 tree model, visualization was made in CloudCompare software (Girardeau-Montaut 2020) 
appearance of a tree. This model represents the external shape of the bark and all its irregularities, allowing the tree volume to be determined very accurately (Fig. 5B, D). According to Dassot et al. (2012), the resulting model can serve as an absolute reference for volume measurements. However, the application of the direct surface reconstruction method requires a very high quality and high density point cloud, as it is very sensitive to the lack of data continuity. Due to the complexity of the forest environment and the fact that trunks and branches obscure each other, this method can only be used for MS mode data. However, it should be noted that even with data collected in this way, certain tree fragments will not be faithfully reproduced, which may result in a model being developed with some shortcomings or deficiencies. An additional disadvantage of this method is the need to pre-select points representing the woody parts of trees.

The second approach, most commonly used, is to fit simple geometric primitives into point cloud segments that re- present the woody parts of trees. The process of creating a three-dimensional model using this method is usually done in stages, from the base of the trunk to the top of the tree. Simple three-dimensional geometric figures, such as a cylinder, circle, ellipse, or sphere (Raumonen et al. 2013; Hackenberg et al. 2015), are iteratively fitted into the point cloud segments, representing small fragments of a trunk or branch. The end result of the modelling is a set of shapes that can be combined into a whole. In these methods, the first stage of processing often involves building the skeleton of a tree $(\mathrm{Du}$ et al. 2019), which allows the model to be decomposed into components, i.e. individual branches. Compared to the previous one, this method produces a generalised image of the tree (Fig. 5C, E). However, it is less sensitive to data gaps. When using this method, the best results are obtained with data from the MS mode. It is also possible to build models of the main trunk based on SS data, as the algorithms for merging simple geometric figures are able to deal with partially incomplete data and interpolate the missing part of stem.
A

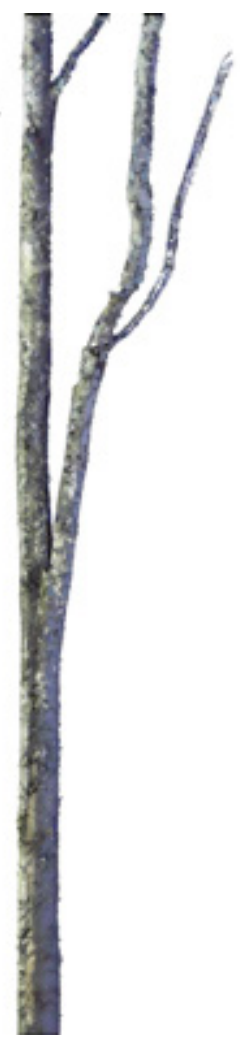

B

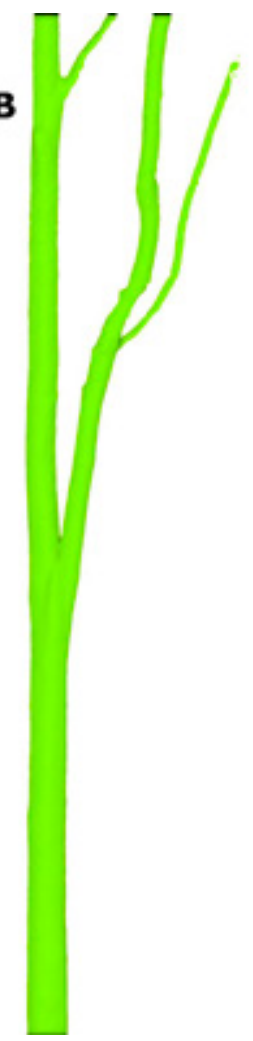

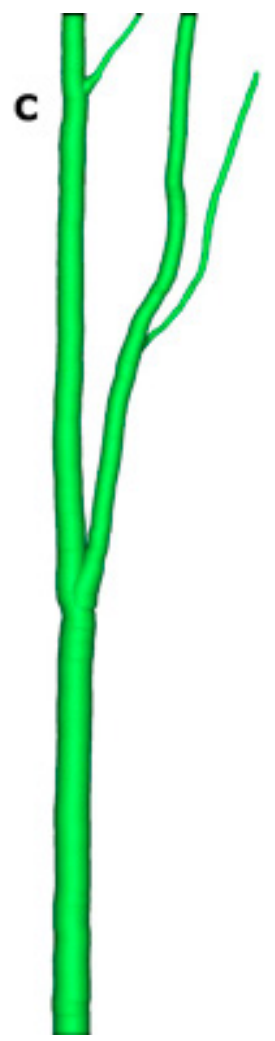
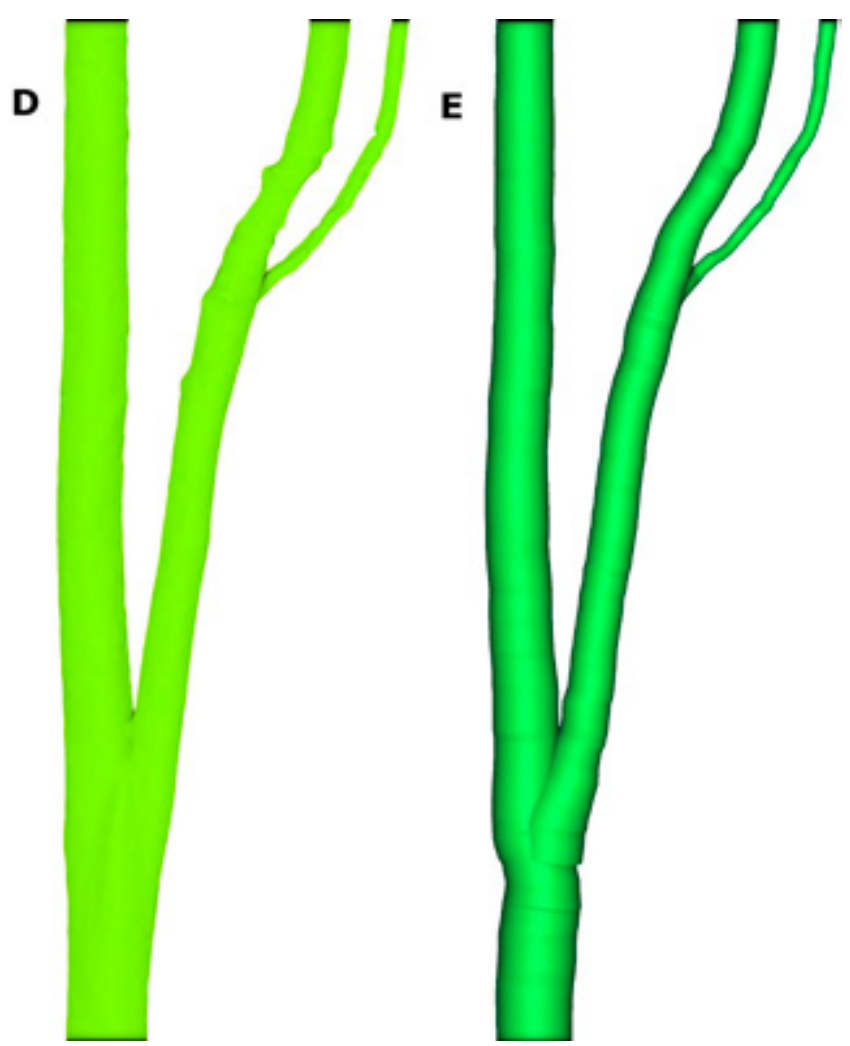

Figure 5. Comparison of quantitative structure models: A - TLS point cloud representing European beech in RGB colors; B, D - tree model obtained by meshing method; C, E - tree model obtained by cylinder fitting method, visualization was made in CloudCompare software (Girardeau-Montaut 2020) 


\subsection{TLS data processing software}

To date, there is no commercial software for working with TLS data that covers all aspects of data processing for forestry purposes. Two companies are developing such software -Treemetrics (Ireland) is developing the AutoStem software (Bienert et al. 2007), while Taxus IT (Poland) is developing thetScan software (Konieczny, Neroj 2016). However, in both cases, they have not yet been included in the sales offer of their companies.

Nevertheless, there are several free solutions (Table 2) that enable such processing of TLS data, developed mainly by scientific centres.

These include standalone desktop applications and libraries of specialised tools used through programming development environments such as Matlab, R, or Python. These tools are publicly available and free of charge.

\section{Assessment of the basic tree parameter estimates obtained by using TLS technology}

In this section, the results of the paper are presented, summarising the achieved accuracy of the estimation of selected basic tree parameters. It should be noted that the obtained results depend on a number of factors such as: Stand structure, assumed sample size, type of scanner used and data processing method applied. The works cited focus on the results obtained for tree stands in the temperate climate zone.

\subsection{Detection of trees in the sample plots}

In 2018, an international academic consortium conducted a comparison of 18 algorithms for processing TLS data from sample plots (Liang et al. 2018b). In the study, reference dendrometric and TLS data were obtained for 24 square plots with side length of $32 \mathrm{~m}$. The selected plots represented three categories depending on the complexity of stand structure: simple - stands with good stem visibility, lack of understory, and tree density of about $600 \mathrm{pcs} / \mathrm{ha}$; medium stands with moderately complex structure, where there are single clumps of understory and tree density is about 1,000 $\mathrm{pcs} / \mathrm{ha}$; and difficult - where there is abundant understory or a second stand layer and tree density is about 2,000 pcs/ ha. The authors of this paper compared the algorithms for many biometric features of trees and for two types of data collection - SS and MS.

Three indicators were proposed to evaluate the tree detection algorithms: detection completeness - it indicates what part of trees in the sample plot was detected, detection correctness - it indicates what part of detected trees was correctly classified as a tree (the algorithm can classify an object that is not a tree), and average detection accuracy - it is a resultant measure of the previous two measures.

The reference data and TLS from this project have been published, making it possible to compare newly developed tree detection algorithms (Zhang et al. 2019, Wang et al. 2020). However, it should be noted that an incomplete dataset was provided, i.e. 6 sample plots, two for each of the stand structure complexity categories.

Below are the tree detection results obtained in the project (Liang et al. 2018b) and other works (Zhang et al. 2019; Wang et al. 2020) using the SS (Table 3) and MS (Table 4) modes.

The above results indicate that the accuracy of tree detection differs depending on the mode of TLS data acquisition used for the analysis (SS or MS), the complexity of the stand structure and its vertical structure.

\subsection{Diameter at breast height measurement}

DBH is the most frequently measured and used biometric parameter of trees in forestry. Table 5 presents the selected results of DBH measurements obtained using two modes of TLS data acquisition. Two error measures are presented in this table: bias, which indicates whether the measurement is over- or underestimated on average, and root mean square error (RMSE), which indicates the average error.

Based on the results of previous work, one can see that the use of the MS mode does not significantly improve the estimation of DBH. On the basis of the above results, it can be assumed that the average error of determining DBH in the SS mode is $1-3 \mathrm{~cm}$, while in the MS mode under $2 \mathrm{~cm}$.

It is worth noting that according to research conducted in Finland in the 1990s, the accuracy of measuring DBH with a tree calliper was about $0.7 \mathrm{~cm}$ (Hyyppä et al. 2018). In the above experiment, an independent measurement of DBH for a fixed group of trees was performed many times by many surveyors, thus eliminating a potential systematic error.

\subsection{Tree height measurement}

The TLS tree height measurement has a systematic error because the upper parts of the tree crown are not well visible. The tops of the trees are obscured by the branches at the bottom of the crown, resulting in a measurement that is usually lower than the actual height. Errors reaching se- 
Table 2. Free software to TLS data processing for forestry purposes

\begin{tabular}{|c|c|c|c|c|c|c|c|}
\hline \multirow[b]{2}{*}{ Name } & \multirow[b]{2}{*}{ Reference } & \multirow[b]{2}{*}{ Platform } & \multicolumn{5}{|c|}{ Algorithms used } \\
\hline & & & $\begin{array}{c}\text { DTM } \\
\text { extraction }\end{array}$ & $\begin{array}{l}\text { Tree stem } \\
\text { detection }\end{array}$ & $\begin{array}{l}\text { Point cloud classifi- } \\
\text { cation into wood/leaf } \\
\text { components }\end{array}$ & $\begin{array}{l}\text { Basic tree } \\
\text { parameters } \\
\text { extraction }\end{array}$ & $\begin{array}{l}\text { QSM } \\
\text { extrac- } \\
\text { tion }\end{array}$ \\
\hline DendroCloud & $\begin{array}{c}\text { Koreň et al. } \\
2017\end{array}$ & $\begin{array}{l}\text { standalone } \\
\text { application }\end{array}$ & + & + & - & + & - \\
\hline 3DForest & $\begin{array}{l}\text { Trochta et } \\
\text { al. } 2017\end{array}$ & $\begin{array}{l}\text { standalone } \\
\text { application }\end{array}$ & + & + & - & + & + \\
\hline Computree* & $\begin{array}{c}\text { Othmani et } \\
\text { al. } 2013\end{array}$ & $\begin{array}{l}\text { standalone } \\
\text { application }\end{array}$ & + & + & - & + & + \\
\hline AdTree & $\begin{array}{c}\text { Du et al. } \\
2019\end{array}$ & $\begin{array}{l}\text { standalone } \\
\text { application }\end{array}$ & - & - & - & + & + \\
\hline SSSC & $\begin{array}{c}\text { Wang et al. } \\
2020\end{array}$ & $\begin{array}{l}\text { standalone } \\
\text { application } \\
\text { and Matlab }\end{array}$ & + & + & + & - & - \\
\hline TreeQSM & $\begin{array}{l}\text { Raumonen } \\
\text { et al. } 2013\end{array}$ & Matlab & - & - & - & + & + \\
\hline
\end{tabular}

*a multifunctional platform designed for processing LiDAR data for forestry purposes, with the possibility of adding external plugins;

**the software has changed its name from SimpleTree;

$* * *$ the Computree platform plug-in

veral metres have been reported in published works (Table 6). Using the MS mode improves the results, but there still remains some error in the height estimates.

\subsection{Tree taper curve measurement}

TLS data allow to reproduce the taper curve of a stem in a non-invasive manner by taking automatic diameter measurements of point cloud sections from different stem heights. When TLS is implemented in operational forestry, it is possible to reconstruct the taper curve for each of the trees in the sample plot.
It should be noted that it is often not possible to reconstruct the entire trunk from the base of the trunk to the top of the tree. This is due to the lack of visibility of the highest parts of the stem, or because its representation in the point cloud is too weak, resulting from the long distance of the scanner to the top of the tree (the distance can be more than $30 \mathrm{~m}$ for tall trees), which means less frequent point sampling.

It is assumed that, on average,the stems of up to $50-70 \%$ of the relative tree height can be reconstructed using TLS in the sample plots (Liang et al. 2018b). Note that this is the part of the stem where most of the tree volume is accumulated. 
Table 3. Results of automatic tree detection on the $32 \times 32 \mathrm{~m}$ sample plots at different levels of stand complexity - single-scan mode

\begin{tabular}{|c|c|c|c|}
\hline Stand complexity & Parameter [\%] & Liang et al. $2018 b$ & Zhang et al. 2019 \\
\hline \multirow[b]{2}{*}{ Easy } & mean accuracy & $\sim 88^{*}$ & 79 \\
\hline & completeness & $\sim 81 *$ & 68 \\
\hline \multirow[b]{2}{*}{ Medium } & mean accuracy & $\sim 73 *$ & 57 \\
\hline & completeness & $\sim 70^{*}$ & 41 \\
\hline \multirow[t]{2}{*}{ Difficult } & completeness & $\sim 34^{*}$ & 11 \\
\hline & correctness & $\sim 95^{*}$ & 95 \\
\hline \multirow{3}{*}{ Mean } & mean accuracy & $57 * *$ & 52 \\
\hline & completeness & $62 * *$ & 40 \\
\hline & correctness & $93 * *$ & 97 \\
\hline
\end{tabular}

*result achieved by the best algorithm,

**mean value calculated from results based on all 18 algorithms

Maas et al. (2008) compared the taper curves of the stem obtained with TLS technology and with a harvester head. An RMSE of $4.7 \mathrm{~cm}$ was obtained with respect to the reference measurements from the harvester. The authors note that the error between stem sections between 0.7 and $7.7 \mathrm{~m}$ was only $1 \mathrm{~cm}$. They also point out that the error on the whole trunk is larger due to the unusual (non-cylindrical) shape of the lower part of the trunk and the large number of branches in its upper part. The specific structure of the studied tree negatively influenced the diameter estimation.

Table 7 shows a summary of the results obtained for the determination of the longitudinal taper curve of the trunk. It contains information about the average longitudinal taper curve in the sample plots. This value expresses the percentage of relative tree height that could be mapped.

\subsection{Determining tree volume}

Using TLS data, it is possible to directly determine the volume of individual trees with an error not exceeding
$10 \%$, which is comparable to the results obtained using the best allometric equations (Dassot et al. 2012; Liang et al. 2014).

In an international comparison of TLS algorithms (Liang et al. 2018b), the best algorithm for data collection in the SS mode achieved an RMSE for single-tree volumes between 25 and $50 \%$, and between 20 and $40 \%$ for the MS mode. In this study, a measure for the overall assessment of the tree volume of the sample plot was proposed by calculating the volume ratio. This is calculated as the quotient of the tree volume determined by TLS and the reference volume. The authors give the average volume ratio for circular plots with three different structures: easy $-94 \%$ for the mode SS and $107 \%$ for the mode MS, medium $-87 \%$ for the mode SS and $107 \%$ for the mode MS and difficult $-43 \%$ for the mode SS and $94 \%$ for the mode MS. These results show that it is possible to determine the volume at the sample plot level in both SS and MS modes with an error of $6-13 \%$ for stands with simple and medium structures. When using the SS mode in plots with difficult struc- 
Table 4. Results of automatic tree detection on the $32 \times 32 \mathrm{~m}$ sample plots at different levels of stand complexity - multi-scan mode

\begin{tabular}{|c|c|c|c|c|}
\hline \multirow{2}{*}{ Stand complexity } & \multirow{2}{*}{ Parameter [\%] } & \multicolumn{3}{|c|}{ Results } \\
\hline & & Liang et al. 2018b* & Zhang et al. 2019 & Wang et al. 2020 \\
\hline \multirow[b]{2}{*}{ Easy } & mean accuracy & $\sim 92 *$ & 90 & 90 \\
\hline & completeness & $\sim 90^{*}$ & 84 & 91 \\
\hline \multirow[b]{2}{*}{ Medium } & mean accuracy & $\sim 88^{*}$ & 74 & 74 \\
\hline & completeness & $\sim 88^{*}$ & 59 & 78 \\
\hline \multirow[t]{2}{*}{ Difficult } & completeness & $\sim 66^{*}$ & 36 & 58 \\
\hline & correctness & $\sim 93^{*}$ & 96 & 69 \\
\hline \multirow{3}{*}{ Mean } & mean accuracy & $69 * *$ & 72 & 76 \\
\hline & completeness & $81^{* *}$ & 60 & 76 \\
\hline & correctness & $92 * *$ & 97 & 76 \\
\hline
\end{tabular}

*result achieved by the best algorithm,

**mean value calculated from results based on all 18 algorithms

ture, the total volume is underestimated by more than $50 \%$. Mode MS, on the other hand, gives very similar results to the reference data ( $6 \%$ difference).

Table 8 shows the results of estimating the volume of the individual trees.

\section{Discussion}

The presented results show the great potential of using TLS technology in forest inventory. However, the introduction of this technology in forest practice is a complicated and time-consuming process. The change from existing solutions to new technologies must bring measurable economic or qualitative benefits.

In terms of forest inventory, the most important factors influencing the adoption of a new measurement technology are: the accuracy of the determination of basic tree characteristics, the cost of the technology (both equipment and software) and aspects relating to the operational use of the technology (technological limitations, time of data acquisition, dimensions of the equipment and the required qualifications of surveyors, including training in the use of the scanner and software). Considering these aspects, the main limitations of using TLS in forestry practice are the cost of the technology, lack of software and aspects relating to its operational use.

Although the price of TLS devices is gradually decreasing, the cost of 100,000-150,000 PLN per device is still too high. Given the current lack of multifunctional commercial TLS data processing software for forestry purposes, it can be assumed that the first ones to appear on the market will also be expensive. This aspect may be the main reason for not implementing this technology in forestry practice in the next few years.

Taking into account aspects of the operational use of TLS technology in forestry, the most difficult one is to ensure the detection of all trees in the sample plots. With the current methodology of taking measurements in circular plots, the MS data acquisition mode can be used in stands 
Table 5. Results of the automatic estimation of the diameter at the breast height based on the TLS point cloud in two data acquisition modes - SS (single-scan) and MS (multi-scan)

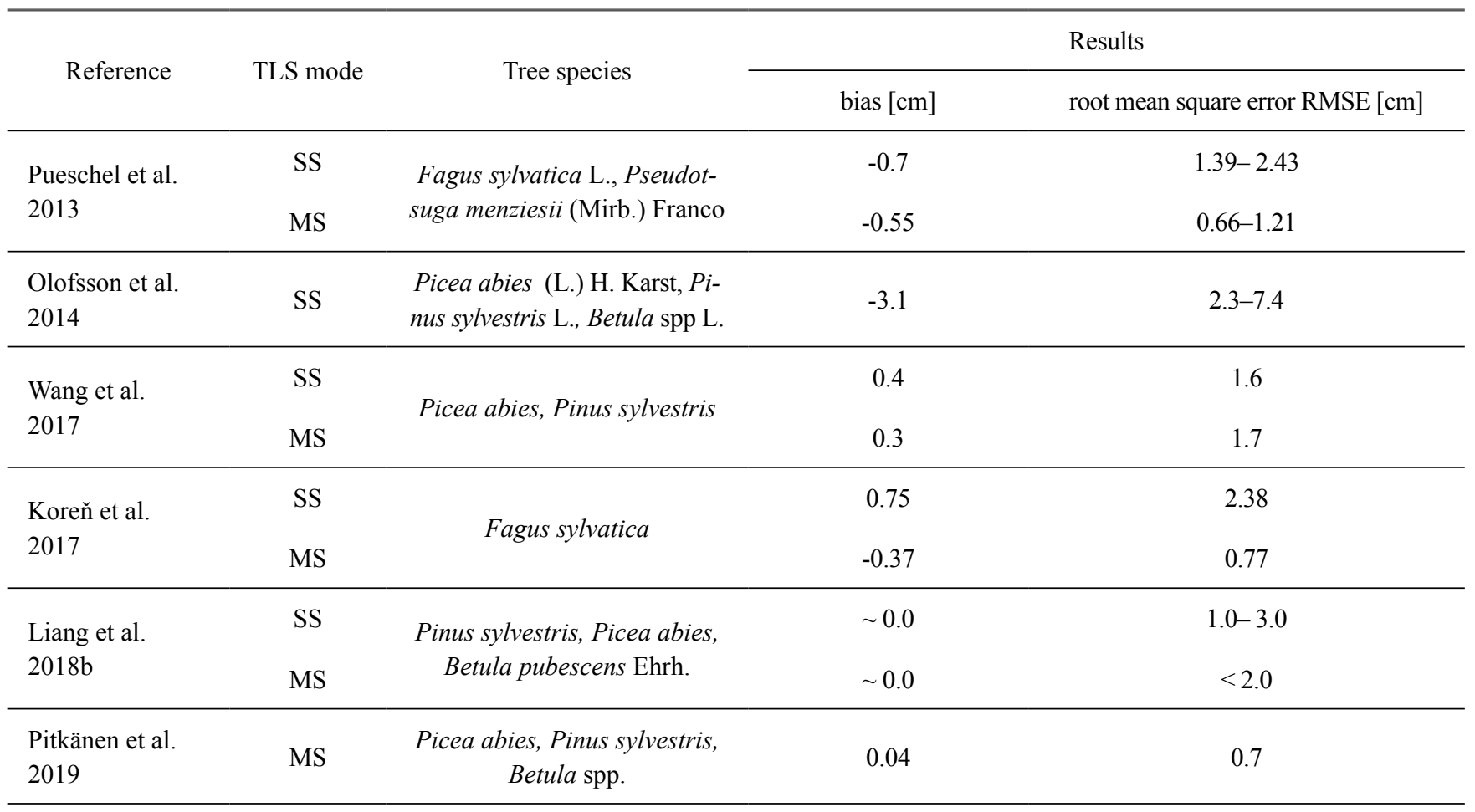

Table 6. Results of the automatic estimation of the tree height based on the TLS point cloud in two data acquisition modes - SS (single-scan) and MS (multi-scan)

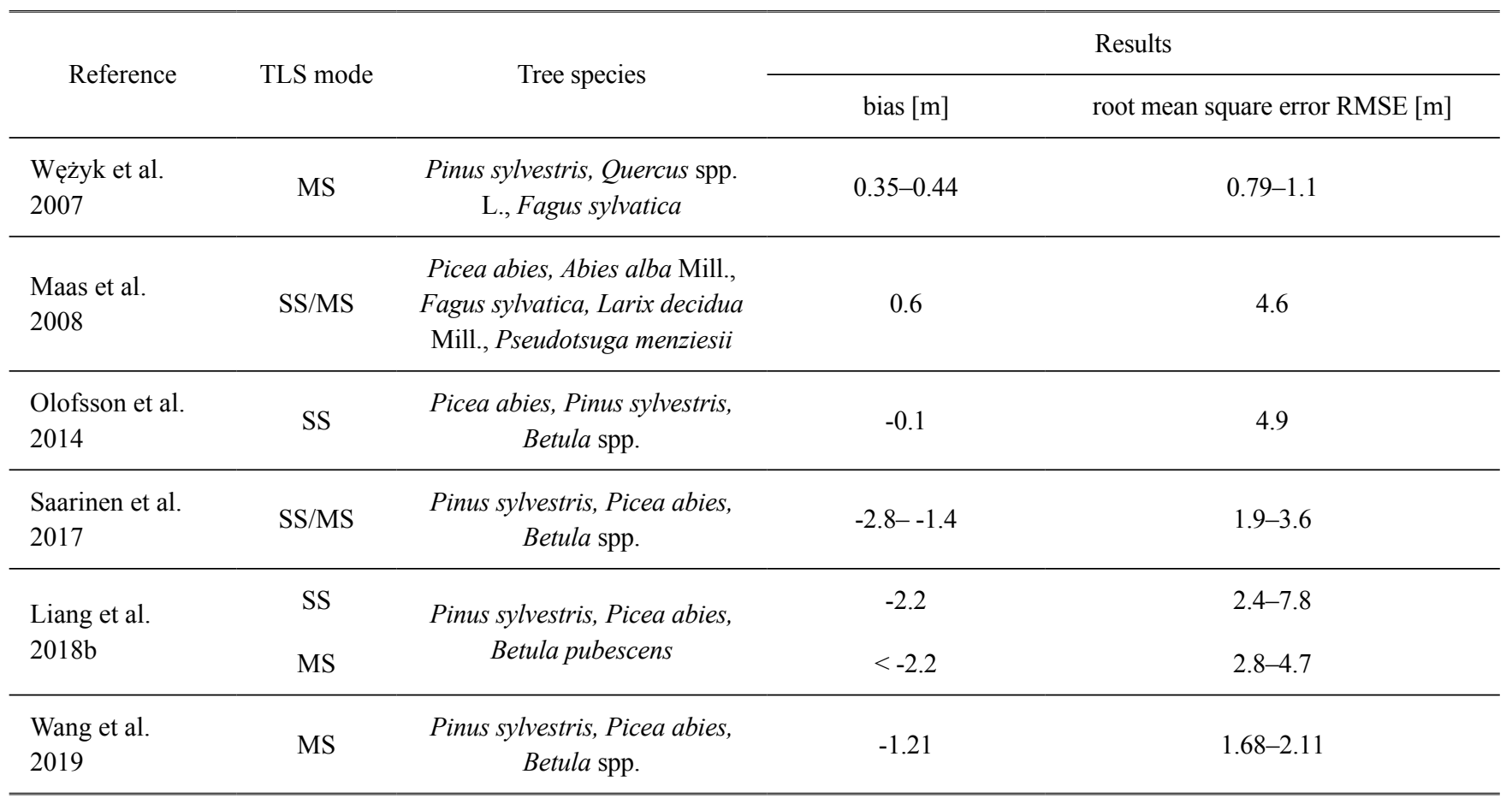


Table 7. Results of the automatic estimation of the tree taper curve based on the TLS point cloud in two data acquisition modes - SS (singlescan) and MS (multi-scan).

\begin{tabular}{|c|c|c|c|c|c|}
\hline \multirow[b]{2}{*}{ Reference } & \multirow[b]{2}{*}{ TLS mode } & \multirow[b]{2}{*}{ Tree species } & \multicolumn{3}{|c|}{ Results } \\
\hline & & & $\begin{array}{l}\text { percentage of the tree } \\
\text { height covered by } \\
\text { measurements }[\%]^{*}\end{array}$ & bias $[\mathrm{cm}]$ & $\begin{array}{l}\text { root mean square } \\
\text { error RMSE }[\mathrm{cm}]\end{array}$ \\
\hline $\begin{array}{l}\text { Maas et al. } \\
2008\end{array}$ & SS & $\begin{array}{c}\text { Picea sitchensis (Bong.) } \\
\text { Carrière }\end{array}$ & - & - & 4.7 \\
\hline $\begin{array}{l}\text { Liang et al. } \\
2014\end{array}$ & MS & $\begin{array}{c}\text { Pinus sylvestris, Picea } \\
\text { abies }\end{array}$ & $61-66$ & 0.15 & 1.13 \\
\hline $\begin{array}{l}\text { Saarinen et al. } \\
2017\end{array}$ & $\begin{array}{l}\text { SS } \\
\text { MS }\end{array}$ & $\begin{array}{l}\text { Pinus sylvestris, Picea } \\
\text { abies, Betula } \mathrm{spp}\end{array}$ & $\begin{array}{l}38-45 \\
58-62\end{array}$ & - & - \\
\hline
\end{tabular}

*mean value

with a simple structure. The results show that with this configuration, all or the vast majority of trees in the sample plots are able to be automatically detected. However, scanning from several positions significantly lengthens the surveyor's working time, which is currently considered to be too long. It is possible that the new generation of scanners will require less time to obtain data, but the cost of such devices will certainly be relatively high at first. Additionally, artificial markers usually have to be set up to align the scans when using the MS mode. The possible development and general availability of algorithms to automatically align scans without the use of targets will certainly be a factor influencing the potential implementation of TLS in forestry practice. So far, there have been several papers on this issue, and such algorithms are available only in a few commercial software programs.

The use of data obtained in the SS mode is competitive compared to the MS mode, but only for trees that are clearly visible in the point cloud. Based on the results of published works, it can be assumed that about $70 \%$ of the trees in a circular plot are detected using the SS mode. If an inventory method based only on visible trees or a correction method for invisible trees was developed, the SS mode would be attractive for forestry practice due to the much shorter time of data acquisition. So far, little work is available on this topic, and further research is required.
Should such methods be developed, it would be possible to use TLS in more complex stands. Worth noting recurrent research results, showing that the determination of some aggregate stand characteristics, e.g. abundance, using both data acquisition modes provides results very similar to the reference data for stands with simple and moderate structures, and using the MS mode - even for stands with a complex structure.

Another potential scenario is the use of TLS SS data to calibrate the methods of estimating survey characteristics using ALS and individual tree detection (ITD) methods. This approach would use only information from clearly visible trees. This topic also requires study and the development of precise methods to align TLS and ALS data with "tree-to-tree" accuracy. Of course, this solution is also very expensive at the moment.

The problem of obscured trees can be solved with mobile laser scanning (MLS). By using this constantly evolving technology, it is possible to design the trajectory of the survey of the sample area in such a way that all trees can be mapped. The use of terrestrial remote sensing techniques such as MS TLS or MLS also makes it possible to increase the size of the sample plots to be considered, which can be an additional advantage in forest inventory.

It is worth mentioning the release of the new version of Apple's flagship product. In March 2020, the company began 
Table 8. Results of the automatic estimation of the tree volume based on the TLS point cloud in two data acquisition modes - SS (singlescan) and MS (multi-scan)

\begin{tabular}{|c|c|c|c|c|}
\hline \multirow[b]{2}{*}{ Reference } & \multirow[b]{2}{*}{ TLS mode } & \multirow[b]{2}{*}{ Tree species } & \multicolumn{2}{|r|}{ Results } \\
\hline & & & bias $[\%]$ & $\begin{array}{c}\text { root mean square error RMSE } \\
{[\%]}\end{array}$ \\
\hline $\begin{array}{l}\text { Dassot et al. } \\
2012\end{array}$ & MS & $\begin{array}{l}\text { Quercus spp., Robinia pseudoaccia L., } \\
\text { Alnus glutinosa, Fraxinus excelsior L., } \\
\text { Tilia coordata Mill., Betula pendula } \\
\text { Roth., Pinus halepensis Mill. }\end{array}$ & $+/-10 *$ & - \\
\hline $\begin{array}{l}\text { Pueschel et al. } \\
2013\end{array}$ & $\begin{array}{l}\text { SS } \\
\text { MS }\end{array}$ & Fagus sylvatica, Pseudotsuga menziesii & $\begin{array}{c}-34-44^{*} \\
-2-6^{*}\end{array}$ & $\begin{array}{l}- \\
-\end{array}$ \\
\hline $\begin{array}{l}\text { Kankare et al. } \\
2013\end{array}$ & MS & Pinus sylvestris, Picea abies & 0.67 & 15.34 \\
\hline $\begin{array}{l}\text { Saarinen et al. } \\
2017\end{array}$ & $\begin{array}{l}\text { SS } \\
\text { MS }\end{array}$ & Pinus sylvestris, Picea abies, Betula spp & $\begin{array}{l}-0.8 \\
4.3\end{array}$ & $\begin{array}{l}12.4 \\
8.5\end{array}$ \\
\hline $\begin{array}{l}\text { Liang et al. } \\
2018 b\end{array}$ & $\begin{array}{l}\text { SS } \\
\text { MS }\end{array}$ & $\begin{array}{c}\text { Pinus sylvestris, Picea abies, Betula } \\
\text { pubescens }\end{array}$ & - & $\begin{array}{l}\sim 20-45 * * * \\
\sim 15-25 * * *\end{array}$ \\
\hline
\end{tabular}

*deviation from the reference value,

$* *$ calculated from publication data,

***the best result among 18 tested algorithms in stands with different structure

selling a new version of the iPad Pro. One of its innovations is a built-in LiDAR sensor. According to the manufacturer, the range of the sensor is up to 5 metres and allows you to reconstruct the nearest environment in three dimensions (Apple Inc. 2020). The price of the basic version of this iPad is currently about 3,900. So far, there are no published works on the use of this tablet in forestry research, but it is expected that soon such studies will be conducted and may be of interest for forestry practise.

Given the continued development of LiDAR technology, one can expect to see the development of laser scanners capable of large-scale aerial mapping of tree trunks in the next decade or so. Assuming that the technology develops in this direction, it will then be possible to directly measure the basic characteristics of individual trees without the need for ground measurements and statistical modelling. It can be assumed that the algorithms developed for TLS data processing could be directly applied to this new type of data.

\section{Conclusions}

1. Over the last 20 years, TLS data processing algorithms for forest inventory purposes have significantly developed.

2. TLS technology can be used for non-invasive dendrometric measurements of trees and stands, with an estimation accuracy of most parameters comparable to traditional measurement methods currently used in forestry.

3. The best time to obtain TLS data for forest inventory purposes is early spring or late autumn (especially in deciduous stands or with the participation of deciduous species in the undergrowth). Scanning is best done in windless weather and low air humidity.

4. Better results for estimating the biometric characteristics of trees can be obtained using the MS data acquisition mode. However, measurements using this mode are much more time-consuming compared to the SS mode. 
5. The TLS data acquisition mode and stand structure have a great influence on the detection of trees and the accuracy of describing their biometric characteristics.

6. Using TLS technology makes it possible to non-invasively measure the taper curve of standing trees up to about $60-70 \%$ of relative tree height.

7. The measurement of tree height is burdened with a relatively large systematic error caused by the 'occlusion effect' - the top of the tree is obscured by the lower part of the crown.

8. Further research is needed on the use of TLS technology in forest inventory and the creation of a set of 'good practices' and instructions on how to obtain and process TLS data, taking into account different variants of their acquisition.

\section{Conflict of interest}

The authors declare the lack of potential conflicts of interest.

\section{Funding sources}

This publication was written within the framework of the REMBIOFOR project 'Remote sensing based assessment of woody biomass and carbon storage in forests' co-financed by the National Centre for Research and Development under the program 'Natural environment, agriculture and forestry' BIOSTRATEG under agreement no. BIOSTRATEG1/267755/4/NCBR/2015.

\section{References}

Apple Inc. 2020. Apple unveils new iPad Pro with breakthrough LiDAR Scanner and brings trackpad support to iPadOS, Apple Inc. https://www.apple.com/pl/newsroom/2020/03/apple-unveils-new-ipad-pro-with-lidar-scanner-and-trackpad-support-in-ipados/ [20.09.2020].

Aschoff T., Spiecker H. 2004. Algorithms for the automatic detection of trees in laser scanner data. International Archives of Photogrammetry, Remote Sensing and Spatial Information Sciences 36(8) / W2: 71-75.

Astrup R., Ducey M., Granhus A., Ritter T., von Lüpke N. 2014. Approaches for estimating stand-level volume using terrestrial laser scanning in a single-scan mode. Canadian Journal for Forest Research 44(6): 666-676. DOI 10.1139/ cjfr-2013-0535.

Będkowski K. 2004. Skanowanie laserowe i jego zastosowanie w leśnictwie. Roczniki Geomatyki 4: 33-40.

Będkowski K., Adamczyk J., Kamińska B., Karaszkiewicz W., Korpetta D., Mozgawa J., Olenderek H., Stereńczak K., Tracz
W., Zarzecka M. 2011. Las w rastrowym modelu danych przestrzennych. Wydawnictwo SGGW, Warszawa, 213 s. ISBN 978-83-7583-335-5.

Bienert A., Scheller S., Keane E., Mohan F., Nugent C. 2007. Tree detection and diameter estimations by analysis of forest terrestrial laserscanner point clouds, in: Proceedings of the ISPRS Workshop 'Laser Scanning 2007 and SilviLaser 2007' (ed. P. Rönnholm, H. Hyyppä, J. Hyyppä), 12 14.09.2007, Espoo, Finland. 12-14.09.2007. IAPRS 36(3) / W52, 50-55.

Brolly G., Kiraly G. 2009. Algorithms for stem mapping by means of terrestrial laser scanning. Acta Silvatica et Lignaria Hungarica 5: 119-130.

Burt A, Disney M, Calders K. 2018. Extracting individual trees from lidar point clouds using treeseg. Methods in Ecology and Evolution 10(3): 438-445. DOI 10.1111/2041-210X.13121.

de Conto T., Olofsson K., Görgens E.B., Rodriguez L.C.E., Almeida G. 2017. Performance of stem denoising and stem modelling algorithms on single tree point clouds from terrestrial laser scanning. Computers and Electronics in Agriculture 143: 165-176. DOI 10.1016/j.compag.2017.10.019.

Chirrek M., Wencel A., Strzeliński P., Zasada M., Zawiła-Niedźwiecki T. 2007. Wykorzystanie technologii naziemnego skaningu laserowego w inwentaryzacji lasu. Roczniki Geomatyki 5(5): 19-24.

Chmielewski L., Bator M., Zasada M., Stereńczak K., Strzeliński P. 2010. Fuzzy Hough transform-based methods for extraction and measurements of single trees in large-volume 3D terrestrial LIDAR data, in: L. Bolc, R. Tadeusiewicz, L.J. Chmielewski, K. Wojciechowski (red.) Computer Vision and Graphics, 265274. DOI 10.1007/978-3-642-15910-7_30.

Côté J.F., Widlowski J.L., Fournier R.A., Verstraete M.M. 2009. The structural and radiative consistency of three-dimensional tree reconstructions from terrestrial lidar. Remote Sensing of Environment 113(5): 1067-1081. DOI 10.1016/j. rse.2009.01.017.

Danson F.M., Gaulton R., Armitage R.P., Disney M., Gunawan O., Lewis P., Pearson G., Ramirez A.F. 2014. Developing a dual-wavelength full-waveform terrestrial laser scanner to characterize forest canopy structure. Agricultural and Forest Meteorology 198: 7-14. DOI 10.1016/j. agrformet.2014.07.007.

Dassot M., Constant T., Fournier M., 2011. The use of terrestrial LiDAR technology in forest science: application fields, benefits and challenges. Annals of Forest Science 68: 959-974. DOI 10.1007/s13595-011-0102-2.

Dassot M., Colin A., Santenoise P., Fournier M., Constant T. 2012. Terrestrial laserscanning for measuring the solid wood volume, including branches, of adult standingtrees in the forest environment. Computers and Electronics in Agriculture 89: 86-93. DOI 10.1016/j.compag.2012.08.005.

Girardeau-Montaut D. 2020. CloudCompare - 3D Point Cloud and Mesh Processing Software (Version 2.11.3). GPL Softw. 2020. http://www.cloudcompare.org/ [14.10.2020]. 
Hackenberg J., Spiecker H., Calders K., Disney M., Raumonen P. 2015. SimpleTree - An efficient open source tool to build tree models from TLS clouds. Forests 6(11): 4245-4294. DOI $10.3390 /$ f6114245.

Hawryło P. 2017. Określanie wybranych cech drzewostanów sosnowych z wykorzystaniem chmur punktów pozyskanych w procesie automatycznego dopasowania cyfrowych zdjęć lotniczych. Sylwan 161(9): 707-714. DOI 10.26202/ sylwan.2017066.

Henning J., Radtke P., 2006. Detailed Stem Measurements of Standing Trees from Ground-Based Scanning Lidar. Forest Science 52(1): 67-80. DOI 10.1093/forestscience/52.1.67.

Hyyppä J., Virtanen J.-P., Jaakkola A., Yu X., Hyyppä H., Liang X. 2018. Feasibility of Google Tango and Kinect for Crowdsourcing Forestry Information. Forests 9(1): 6. DOI 10.3390/ f9010006.

Kangas A., Astrup R., Breidenbach J., Fridman J., Gobakken T., Korhonen K., Maltamo M., Nilsson M, Nord-Larsen T., Næsset E., Olsson H. 2018. Remote sensing and forest inventories in Nordic countries - roadmap for the future. Scandinavian Journal of Forest Research 33(4): 397-412. DOI 10.1080/02827581.2017.1416666.

Kankare V., Holopainen M., Vastaranta M., Puttonen E., Yu X., Hyyppä J., Vaaja M., Hyyppä H., Alho P. 2013. Individual tree biomass estimation using terrestrial laser scanning. ISPRS Journal of Photogrammetry and Remote Sensing 75: 64-75. DOI 10.1016/j.isprsjprs.2012.10.003.

Konieczny A., Neroj B. 2016. Projekt działania programu do obliczania miąższości drzew na podstawie danych skanowania naziemnego (TLS), prezentacja z „Narada Koordynatorów SIP”, Zakopane, 23-25.02.2016 r. https://www.geomatyka.lasy.gov. pl/documents/25999395/0/Konieczny-TLS.pdf/b13219cc1608-4004-8692-2de4d0d44a5e [12.11.2020].

Koreň M., Mokroš M., Bucha T. 2017. Accuracy of tree diameter estimation from terrestrial laser scanning by circle-fitting methods. International Journal of Applied Earth Observation and Geoinformation 63: 122-218. DOI 10.1016/j.jag.2017.07.015.

Li Z., Douglas E., Strahler A., Schaaf C., Yang X., Wang Z., Yao T., Zhao F., Saenz E.J., Paynter I. 2013. Separating leaves from trunks and branches with dual-wavelength terrestrial LiDAR scanning, in: Proceedings of the 2013 IEEE International Geoscience and Remote Sensing Symposium (IGARSS), Melbourne, VIC, Australia, 21-26 July 2013, 3383-3386. DOI 10.1109/IGARSS.2013.6723554.

Liang X., Litkey P., Hyyppä J., Kaartinen H., Vastaranta M., Holopainen M. 2012. Automatic stem mapping using single-scan terrestrial laser scanning. IEEE Transactions on Geoscience and Remote Sensing 50: 661-670. DOI 10.1109/ TGRS.2011.2161613.

Liang X., Kankare V., Yu X., Hyyppä J., Holopainen M. 2014. Automated stem curve measurement using terrestrial laser scanning. IEEE Transactions on Geoscience and Remote Sensing, 52(3): 1739-1748. DOI 10.1109/TGRS.2013.2253783.
Liang X., Kankare V., Hyyppä J., Wang Y., Kukko A., Haggrén H., Yu X., Kaartinen H., Jaakkola A., Guan F., Holopainen M., Vastaranta M. 2016. Terrestrial laser scanning in forest inventories. ISPRS Journal of Photogrammetry and Remote Sensing 115: 63-77. DOI 10.1016/j.isprsjprs.2016.01.006.

Liang X., Kukko A., Hyyppä J., Lehtomäki M., Pyörälä J., Yu X., Kaartinen H., Jaakkola A., Wang Y. 2018a. In-situ measurements from mobile platforms: An emerging approach to address the old challenges associated with forest inventories. ISPRS Journal of Photogrammetry and Remote Sensing 143: 97-107. DOI 10.1016/j.isprsjprs.2018.04.019.

Liang X., Hyyppä J., Kaartinen H., Lehtomäki M., Pyörälä J., Pfeifer N., Holopainen M., Brolly G., Francesco P., Hackenberg J., Huang H., Jo H-W., Katoh M., Liu L., Mokroš M., Morel J., Olofsson K., Poveda-Lopez J., Trochta J., Wang D., Wang J., Xi Z., Yang B., Zheng G., Kankare V., Luoma V., Yu X., Chen L., Vastaranta M., Saarinen N., Wang Y. 2018 b. International benchmarking of terrestrial laser scanning approaches for forest inventories. ISPRS Journal of Photogrammetry and Remote Sensing 144: 137-179. DOI 10.1016/j. isprsjprs.2018.06.021.

Lindberg E., Holmgren J., Olofsson K., Olsson H. 2012. Estimation of stem attributes using a combination of terrestrial and airborne laser scanning. European Journal of Forest Research 131: 1917-1931. DOI 10.1007/s10342-012-0642-5.

Maas H., Bienert A., Scheller S., Keane E. 2008. Automatic forest inventory parameter determination from terrestrial laser scanner data. International Journal of Remote Sensing 29(5): 1579-1593. DOI 10.1080/01431160701736406.

Næsset, E. 2002. Predicting forest stand characteristics with airborne scanning laser using a practical two-stage procedure and field data. Remote Sensing of Environment 80: 88-99. DOI 10.1016/S0034-4257(01)00290-5.

Olofsson K., Holmgren J., Olsson H. 2014. Tree stem and height measurements using terrestrial laser scanning and the RANSAC algorithm. Remote Sensing 6: 4323-4344. DOI 10.3390/ rs6054323.

Olofsson K., Holmgren J. 2016. Single Tree stem profile detection using terrestrial laser scanner data, flatness saliency features and curvature properties. Forests 7: 207. DOI 10.3390/ f7090207.

Pitkänen T.P., Raumonen P., Kangas A. 2019. Measuring stem diameters with TLS in boreal forests by complementary fitting procedure. ISPRS Journal of Photogrammetry and Remote Sensing 147: 294-306. DOI 10.1016/j.isprsjprs.2018.11.027.

Pueschel P., Newnham G., Rock G., Udelhoven T., Werner W., Hill J. 2013. The influence of scan mode and circle fitting on tree stem detection, stem diameter and volume extraction from terrestrial laser scans. ISPRS Journal of Photogrammetry and Remote Sensing 77: 44-56. DOI 10.1016/j. isprsjprs.2012.12.001.

Raumonen P., Kaasalainen M., Åkerblom M., Kaasalainen S., Kaartinen H., Vastaranta M., Holopainen M., Disney M., Lewis P. 2013. Fast automatic precision tree models from terrestrial 
laser scanner data. Remote Sensing 5: 491-520. DOI 10.3390/ rs5020491.

Ratajczak M., Wężyk P. 2015. Automatyczne określanie średnicy pnia, podstawy korony oraz wysokości sosny zwyczajnej (Pinus silvestris L.) na podstawie analiz chmur punktów 3D pochodzących z wielostanowiskowego naziemnego skanowania laserowego. Archiwum Fotogrametrii, Kartografii i Teledetekcji 27: 123-138. DOI 10.14681/afkit.2015.009.

Riegl 2020. Riegl VZ-400i. Riegl Laser Measurement System GmbH, Austria. http://www.riegl.com/uploads/tx_pxpriegldownloads/RIEGL_VZ-400i_Datasheet_2020-10-06 [20.10.2020].

Seidel D., Fleck S., Leuschner C. 2012. Analyzing forest canopies with ground-based laser scanning: A comparison with hemispherical photography. Agricultural and Forest Meteorology 154-155: 1-8. DOI 10.1016/j.agrformet.2011.10.006.

Stereńczak K. 2010. Technologia lotniczego skanowania laserowego jako źródło danych w półautomatycznej inwentaryzacji lasu. Sylwan 154(2): 88-99. DOI 10.26202/sylwan.2009041.

Stereńczak K., Lisańczuk M., Parkitna K., Mitelsztedt K., Mroczek P., Miścicki S. 2018. The influence of number and size of sample plots on modelling growing stock volume based on airborne laser scanning. Drewno 61(201): 5-22. DOI 10.12841/ wood.1644-3985.D11.04.

Tanaka T., Yamaguchi J., Takeda Y. 1998. Measurement of forest canopy structure with a laser plane range-finding method - Development of a measurement system and applications to real forests. Agricultural and Forest Meteorology 91: 149-160.

Tompalski P. 2009. Naziemny skaning laserowy w inwentaryzacji zieleni miejskiej na przykładzie Plant w Krakowie. Archiwum Fotogrametrii, Kartografii i Teledetekcji 20: 421-431.

Trochta J., Krůček M., Vrška T., Král K. 2017. 3D Forest: An application for descriptions of three-dimensional forest structures using terrestrial LiDAR. Plos One 12: e0176871. DOI 10.1371/ journal.pone.0176871.

Vaaja M.T., Virtanen J.P., Kurkela M., Lehtola V., Hyyppä J., Hyyppä H. 2016. The effect of wind on tree stem parameter estimation using terrestrial laser scanning. ISPRS Annals of the Photogrammetry, Remote Sensing and Spatial Information Sciences III-8: 117-122. DOI 10.5194/isprs-annals-III-8-117-2016.

Vicari M.B., Disney M., Wilkes P., Burt A., Calders K., Woodgate W. 2019. Leaf and wood classification framework for terrestrial LiDAR point clouds. Methods in Ecology and Evolution 10(5): 1-15. DOI 10.1111/2041-210X.13144.

Wang D., Kankare V., Puttonen E., Hollaus M., Pfeifer N. 2017. Reconstructing stem cross section shapes from terrestrial laser scanning. IEEE Geoscience and Remote Sensing Letters 14: 272-276. DOI 10.1109/LGRS.2016.2638738.

Wang D. 2020. Unsupervised semantic and instance segmentation of forest point clouds, ISPRS Journal of Photogrammetry and Remote Sensing165: 86-97. DOI 10.1016/j. isprsjprs.2020.04.020.

Wang Y., Lehtomäki M., Liang X., Pyörälä J., Kukko A., Jaakkola A., Liu J., Feng Z., Chen R., Hyyppä J. 2019. Is field-measured tree height as reliable as believed - A comparison study of tree height estimates from field measurement, airborne laser scanning and terrestrial laser scanning in a boreal forest. ISPRS Journal of Photogrammetry and Remote Sensing 147: 132-145. DOI 10.1016/j.isprsjprs.2018.11.008.

Wężyk P. 2006. Wprowadzenie do technologii skaningu laserowego w leśnictwie. Roczniki Geomatyki 4 (4): 119-132.

Wężyk P. 2010. Naziemny skaning laserowy, w: Geomatyka w Lasach Państwowych - Cześć I. Podstawy. Centrum Informacyjne Lasów Państwowych, Warszawa, 343-357. ISBN 978-83-61633-01-3.

Wężyk P., Koziol K., Glista M., Pierzchalski M. 2007. Terrestrial laser scanning versus traditional forest inventory. first results from the Polish forests, in: Proceedings of the ISPRS Workshop 'Laser Scanning 2007 and SilviLaser 2007' (ed. P. Rönnholm, H. Hyyppä, J. Hyyppä), 12-14.09.2007, Espoo, Finland. IAPRS 36, 3 / W52, 424-429.

Wężyk P., Sroga R. 2010. Naziemny skaning laserowy w inwentaryzacji miąższości drzewostanów sosnowych. Roczniki Geomatyki 8, 7(43): 63-73.

Wężyk P., Szostak M., Zięba K., Rysiak P., Hawryło P., Ratajczak M. 2015. Preliminary results of the monumental tree monitoring based on terrestrial laser scanning - a case study of the Oak Bartek in Zagnańsk (Poland). Archiwum Fotogrametrii, Kartografii i Teledetekcji 27: 185-200. DOI 10.14681/afkit.2015.014.

White J., Wulder M., Varhola, A., Vastaranta M., Coops N., Cook B., Pitt D., Woods M. 2013. A best practices guide for generating forest inventory attributes from airborne laser scanning data using an area-based approach. Information report FI-X-010, Natural Resources Canada, Canadian Forest Service, Canadian Wood Fibre Centre. DOI 10.5558/ tfc2013-132.

White J., Coops N., Wulder M., Vastaranta M., Hilker T., Tompalski P. 2016. Remote sensing technologies for enhancing forest inventories: A review. Canadian Journal of Remote Sensing 42(5): 619-641. DOI 10.1080/07038992.2016.1207484.

Wilkes P., Lau A., Disney M., Calders K., Burt A., de Tanago J., Bartholomeus H., Brede B., Herold M. 2017. Data acquisition considerations for Terrestrial Laser Scanning of forest plots. Remote Sensing of Environment 196: 140-153. DOI 10.1016/j. rse.2017.04.030.

Zasada M., Stereńczak K. 2013. Dokładność określania wybranych parametrów rozkładów pierśnic drzew w drzewostanach sosnowych za pomocą naziemnego skanowania laserowego. Sylwan 157(12): 883-891. DOI 10.26202/sylwan.2013084.

Zasada M., Stereńczak K., Dudek W., Rybski A. 2013. Horizon visibility and accuracy of stocking determination on circular sample plots using automated remote measurement techniques. Forest Ecology and Management 302: 171-177. DOI 10.1016/j.foreco.2013.03.041.

Zawiła-Niedźwiecki T., Stereńczak K., Bałazy R., Węcel A., Strzeliński P., Zasada M. 2008. The use of terrestrial and airborne lidar technology in forest inventory. Ambiencia 4: 57-68. 
Zhang W., Wan P., Wang T., Cai S., Chen Y. 2019. A novel approach for the detection of standing tree stems from plot-level terrestrial laser scanning data. Remote Sensing 11(2): 211. DOI 10.3390/rs11020211.

Zhou J., Wei H., Zhou G., Song L. 2019. Separating leaf and wood points in terrestrial laser scanning data using multiple optimal scales. Sensors 19: 1852. DOI 10.3390/s19081852.

\section{Authors' contributions}

G.K. - concept development, manuscript preparation, literature review, preparation of figures and tables, editing; B.K. - concept development, editing; K.S. - concept development, editing. 